\title{
Psychological impact of COVID-19 pandemic among healthcare workers in Paraguay: A descriptive and preliminary study
}

\author{
Impacto psicológico de la pandemia de COVID-19 en trabajadores de la salud en \\ Paraguay: un estudio descriptivo y preliminar
}

\author{
Jorge Villalba-Arias $\mathbb{B}^{1}$, Gladys Estigarribia $\mathbb{B}^{1}$, José Andrés Bogado $\mathbb{B}^{1}$, Julieta Méndez $\mathbb{B}^{2}$, Santiago Toledo $\mathbb{( D}^{1}$, \\ Israel González $\mathbb{B}^{3}$, João Mauricio Castaldelli-Maia $\mathbb{B}^{4,5}$, Antonio Ventriglio $\mathbb{1}^{6}$, Julio Torales $\mathbb{B}^{3}$
}

\begin{abstract}
${ }^{1}$ Universidad Nacional de Asunción, Departamento de Psiquiatría (Filial Santa Rosa), Santa Rosa del Aguaray, Paraguay.
2Universidad Nacional de Caaguzú, Instituto Regional para la Investigación en Salud, Coronel Oviedo, Paraguay.

3Universidad Nacional de Asunción, Departamento de Psiquiatría, San Lorenzo, Paraguay.

${ }^{4}$ Fundação do ABC, Medical School, Department of Neuroscience, Santo André, SP, Brazil.

5University of São Paulo, Medical School, Department of Psychiatry, São Paulo, SP, Brazil.

6University of Foggia, Department of Clinical and Experimental Medicine, Foggia, Italy.
\end{abstract}

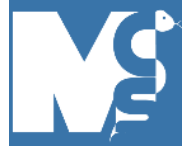

Received: $12 / 05 / 2020$

Revised: 15/08/2020

Accepted: 22/09/2020

\section{Corresponding author}

Julio Torales

National University of Asunción

San Lorenzo - Paraguay

jtorales@med.una.py

\section{Conflicts of interests}

The authors declare that there is no conflict of interest.

\section{Funding}

The authors received no financial support for the research, authorship, and/or publication of this article.

This article is published under Creative Commons Attribution 4.0 International License.

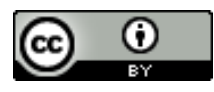

\section{ABSTRACT}

Introduction: Healthcare workers exposed to SARS-CoV-2 are vulnerable to psychological distress. Methodology: A descriptive cross-sectional study was carried out in 5 tertiary hospitals in the Central, San Pedro and Caaguazú Departments of Paraguay during the COVID-19 pandemic from April to June 2020. The pilot study included 125 healthcare workers as participants, 25 for each hospital. Demographic data and occupational exposure data were collected with an ad-hoc questionnaire. Symptoms of depression and anxiety were evaluated employing the Patient Health Questionnaire-9, and the Generalized Anxiety Disorder scale-7. The prevalence of post-traumatic stress was determined using the Post-Traumatic Stress Disorder Check List-C. Results: Of the 125 participants, 68 (54.8\%) were doctors, 37 (29.8) nurses, 7 (5.6\%) biochemists, $3(2.4 \%)$ obstetricians, and $9(7.3 \%)$ other healthcare workers. Most participants were females (86 [68.8\%]), with an average age of 33.8 years (SD \pm 7.4$)$, single (71 [56.8\%]), with a postgraduate educational level (83 [66.4\%]), and reporting a junior level of work experience (52 [41.6\%]). A total of 71 (57.3\%) were classified as high-risk healthcare workers after exposure to SARS-CoV-2. 61 (48.8\%) of participants presented symptoms of depression, and 68 (54.4\%) presented symptoms of anxiety. Conclusion: Healthcare workers in Paraguay reported a significant prevalence of depressive and anxious symptoms during the COVID-19 pandemic. These findings lend support to the idea that healthcare workers are vulnerable to psychological distress and that they may require specific mental health interventions.

Keywords: Healthcare workers; mental health; COVID-19; anxiety; depression; post-traumatic stress

\section{RESUMEN}

Introducción: los trabajadores de la salud expuestos al SARS-CoV-2 son vulnerables a la angustia psicológica. Metodología: se realizó un estudio descriptivo transversal en 5 hospitales de tercer nivel de los Departamentos Central, San Pedro y Caaguazú de Paraguay durante la pandemia de COVID-19, de abril a junio de 2020. El estudio piloto incluyó a 125 trabajadores de la salud, 25 de cada hospital. Los datos demográficos y sobre la exposición ocupacional se recopilaron con un cuestionario ad-hoc. Los síntomas de depresión y ansiedad se evaluaron empleando la escala Patient Health Questionnaire-9 y la escala Generalized Anxiety Disorder scale-7. La prevalencia de estrés postraumático fue determinada usando la escala Post-Traumatic Stress Disorder Check List-C. Resultados: de los 125 participantes, $68(54,8 \%)$ eran médicos, $37(29,8)$ enfermeros, $7(5,6 \%)$ bioquímicos, $3(2,4 \%)$ obstetras y $9(7,3 \%)$ otros trabajadores de la salud. La mayoría de los participantes eran mujeres (86 [68,8\%]), con una edad media de 33,8 años (DE \pm $7,4)$, solteros $(71[56,8 \%])$, con un nivel de estudios de posgrado $(83[66,4 \%])$, y reportaban un nivel junior de experiencia laboral $(52[41,6 \%])$. Un total de $71(57,3 \%)$ fueron clasificados como trabajadores de la salud de alto riesgo después de la exposición al SARS-CoV-2. 61 (48,8\%) de los participantes presentaron síntomas de depresión y $68(54,4 \%)$ presentaron síntomas de ansiedad. Conclusión: los trabajadores de la salud en Paraguay reportaron una prevalencia significativa de síntomas depresivos y ansiosos durante la pandemia de COVID-19. Estos hallazgos apoyan la idea de que los trabajadores de la salud son vulnerables a la angustia psicológica y que pueden requerir intervenciones específicas de salud mental.

Palabras clave: trabajadores de la salud; salud mental; COVID-19; ansiedad; depresión; estrés postraumático 


\section{INTRODUCTION}

Designing special interventions aimed at protecting the mental health of healthcare has become a particularly crucial public health issue during the COVID-19 pandemic (1). Measuring the impact of psychological distress in this vulnerable population may help in the design of these interventions (2).

Previous studies carried out during the SARS (SevereAcute Respiratory Syndrome) epidemic of 2003 confirmed the presence of adverse psychological reactions among healthcare workers (3-5). Healthcare workers reported fear getting infected, and of passing the infection to their family, friends, and colleagues; they also reported feelings of uncertainty and stigmatization. In addition, they showed increased levels of subjective stress, anxiety, and depressive symptoms (5). Also, in 2003, hospital employees exposed to SARS (due to quarantining themselves, or to working in high-risk settings such as SARS wards), as well as those who reported having friends or family members with SARS, were more likely to show symptoms of post-traumatic stress, compared to those without any exposure (6).

In 2020, in the Wuhan region, the original epicenter of COVID-19 pandemic, it has been described that frontline healthcare workers, exposed to patients with COVID-19, reported a significantly higher rate of anxious symptoms, depression, insomnia and malaise, compared to unexposed healthcare workers (7).

In Latin America some studies have been carried out to determine the psychological effects of the COVID-19 pandemic on the general population $(8,9)$. However, data on the psychological impact of the pandemic in Latin American healthcare workers are not available.

The aim of the present study is to describe the psychological impact of COVID-19 among healthcare workers in Paraguay. Findings may provide helpful evidence that could become the basis of strategies designed for the prevention and promotion of mental health in healthcare workers.

\section{METHODOLOGY}

This is a preliminary study carried out in five tertiary referral centers in the departments of Central, San Pedro and Caaguazú, Paraguay, during the two-month period from April to June 2020. The participants included healthcare workers, with age ranging from 18 to 65 years. The tertiary referral hospitals included in this pilot study were the following: "Hospital de Clínicas" in the city of San Lorenzo; General Hospital of the Department of San Pedro, in the city of Santa Rosa del Aguaray; Regional Hospital of the city of Coronel
Oviedo, IPS Hospital of the City of Coronel Oviedo, and Regional Hospital of the city of Pedro Juan Caballero. All the participants were selected using an intentional, non-probabilistic sampling. 125 participants, 25 from each hospital, were included.

The study was approved by the Ethics Committee of the Faculty of Medical Sciences of the National University of Asunción. Informed consent was obtained verbally and in writing by each participant before starting the research recruitment and data collection. Confidentiality of the information was ensured. However, personal contact information was also collected in order to provide further assessment and management if required.

Demographic data included occupation (nurse, doctor, others), sex (male or female), age (21-30, 31-40, 41-50, 51-60 years old), marital status, educational level (undergraduate, graduate or postgraduate), place of residence (urban or rural), type of hospital (secondary, tertiary), and area of work.

Healthcare workers responded to questions regarding their exposure to severe acute respiratory syndrome coronavirus 2 (SARS-CoV-2), including occupational exposure or a friend and/or family member with COVID-19. Occupational exposure was considered as high for those workers practicing in high-risk settings (COVID-19 ward, emergency department, respiratory medicine department, or X-ray imaging) during the pandemic. COVID-19 diagnosis was considered as well as having been in direct contact with a COVID-19 positive patient either at work, home, or in any other setting.

The present study detected symptoms of depression, anxiety and post-traumatic stress disorder, employing instruments with a validated Spanish version: The Patient Health Questionnaire (PHQ-9, range 0-27) (10, $11)$, and the 7- item Generalized Anxiety Disorder scale (GAD-7, range, 0-21) (12). For the assessment of PTSD (Post- Traumatic Stress Disorder) symptoms, the PCL-C PTSD- checklist was used (13), with a score $\geq 50$ indicating significant symptoms of PTSD (14-16).

Because of social distancing rules and the lockdown instituted by the government, data were collected through Google forms, sent by various digital platforms of communication, including e-mails, or digital version of a self-administered form, through Epi-info 7, provided through a tablet. Data were transferred into a Microsoft Excel electronic spreadsheet, version 19.

\section{RESULTS}

In the present pilot study, 125 healthcare workers were selected and completed the survey. Of them, 68 
(54.8\%) were doctors, 37 (29.8\%) nurses, 7 (5.6\%) biochemists, 3 (2.4\%) obstetricians, and 9 (7.3\%) other healthcare workers.

Most participants were females (86 [68.8\%]), with an average age of 33.8 years old (SD \pm 7.4 ); 71 [56.8\%] were single, $83(66.4 \%)$ reported a postgraduate educational level, 52 (41.6\%) with a junior level of work experience. 71 (57.3\%) were considered to be high-risk healthcare workers due to practicing in COVID-19 wards, emergency departments, respiratory medicine departments or X-ray imaging. Most of participants were from urban areas (118 [94.4\%]). 61 (48.8\%) participants presented depressive symptoms, and 68 (54.4\%) reported anxious symptoms. A small group reported symptoms of post-traumatic stress (9 [7.2\%]). Detailed results are shown in Table 1.

TABLE 1. CHARACTERISTICS OF THE SAMPLE ( $\mathrm{N}=125)$.

\begin{tabular}{|c|c|c|c|c|}
\hline Characteristics & n (\%) & $\begin{array}{c}\text { PTSD symptoms } \# \\
n(\%)\end{array}$ & $\begin{array}{c}\text { Depressive } \\
\text { Symptoms } \\
\text { n (\%) }\end{array}$ & $\begin{array}{c}\text { Anxiety } \\
\text { Symptom* } \\
\text { n (\%) }\end{array}$ \\
\hline \multicolumn{5}{|l|}{ Sex } \\
\hline Male & $39(31.2)$ & $4(10.2)$ & $15(38.5)$ & $20(51.2)$ \\
\hline Female & $86(68.8)$ & $5(5.8)$ & $46(53.5)$ & $48(55.8)$ \\
\hline Total & $125(100)$ & $9(7.2)$ & $61(48.8)$ & $68(54.4)$ \\
\hline \multicolumn{5}{|l|}{ Age (years old) } \\
\hline & $33.8 \pm 7.4$ & $31.4 \pm 4.1$ & $33.5 \pm 7.5$ & $33.6 \pm 7.3$ \\
\hline \multicolumn{5}{|l|}{ Marital Status } \\
\hline Married & $38(30.4)$ & $1(2.6)$ & $15(39.5)$ & $22(57.9)$ \\
\hline Divorced/Separated & $7(5.6)$ & $1(14.3)$ & $6(85.7)$ & $5(71.4)$ \\
\hline Domestic Partnership & $5(4.0)$ & $0(0)$ & $0(0)$ & $0(0)$ \\
\hline Single & $71(56.8)$ & $7(9.9)$ & $38(53.5)$ & $40(56.3)$ \\
\hline Widow & $4(3.2)$ & $0(0)$ & $2(50)$ & $1(25)$ \\
\hline \multicolumn{5}{|l|}{ Residence } \\
\hline Rural & $7(5.6)$ & $0(0)$ & $3(42.8)$ & $3(42.8)$ \\
\hline Urban & $118(94.4)$ & $9(7.6)$ & $58(49.1)$ & $65(55.1)$ \\
\hline \multicolumn{5}{|l|}{ Educational Level } \\
\hline Technician & $2(1.6)$ & $0(0)$ & $1(50)$ & $1(50)$ \\
\hline Graduate student & $1(0.8)$ & $0(0)$ & $1(100)$ & $0(0)$ \\
\hline Graduate completed & $39(31.2)$ & $1(2.6)$ & $20(51.3)$ & $23(58.9)$ \\
\hline Post graduate (specialty doctor) & $59(47.2)$ & $8(13.5)$ & $25(42.3)$ & $29(49.1)$ \\
\hline Post graduate (internship) & $16(12.8)$ & $0(0)$ & $9(56.2)$ & $9(56.25)$ \\
\hline Post graduate (MSc) & $8(6.4)$ & $0(0)$ & $5(62.5)$ & $6(75)$ \\
\hline \multicolumn{5}{|l|}{ Occupation } \\
\hline Nurse & $37(29.8)$ & $2(5.4)$ & $18(48.6)$ & $19(51.3)$ \\
\hline Biochemist & $7(5.6)$ & $0(0)$ & $4(57.1)$ & $5(71.4)$ \\
\hline Doctor (Physician) & $68(54.8)$ & $6(8.82)$ & $30(44.1)$ & $37(54.4)$ \\
\hline Obstetrician & $3(2.4)$ & $0(0)$ & $2(66.7)$ & $1(33.3)$ \\
\hline Other & $9(7.3)$ & $0(0)$ & $7(77.7)$ & $4(44.4)$ \\
\hline \multicolumn{5}{|l|}{ Work Experience } \\
\hline Junior level (less than 5 years) & $52(41.6)$ & $5(9.6)$ & 27 (51.9) & $26(50)$ \\
\hline Intermediate level ( 5 -10 years) & $31(24.8)$ & $4(12.9)$ & $14(45.1)$ & $18(58.1)$ \\
\hline Senior level (more than 10 years) & $42(33.6)$ & $0(0)$ & $20(47.6)$ & $24(57.1)$ \\
\hline \multicolumn{5}{|l|}{ Frontline Healthcare workers } \\
\hline Yes & $71(57.3)$ & $7(9.8)$ & $33(46.5)$ & $38(53.5)$ \\
\hline No & $53(42.7)$ & $1(1.9)$ & $28(52.8)$ & $30(56.6)$ \\
\hline \multicolumn{5}{|l|}{ Positive COVID-19 Diagnosis } \\
\hline Yes & $33(26.4)$ & $5(15.15)$ & $17(51.5)$ & $20(60.6)$ \\
\hline No & $92(73.6)$ & $4(4.3)$ & $44(47.8)$ & $48(52.2)$ \\
\hline \multicolumn{5}{|l|}{ Relatives or Friends with Positive } \\
\hline \multicolumn{5}{|l|}{ COVID-19 Diagnosis } \\
\hline Yes & $14(11.2)$ & $2(14.3)$ & $7(50)$ & $7(50)$ \\
\hline No & $111(88.8)$ & $7(6.3)$ & $54(48.6)$ & $61(54.9)$ \\
\hline \multicolumn{5}{|l|}{ Tertiary Hospital } \\
\hline $\begin{array}{l}\text { "Hospital de Clínicas" - San } \\
\text { Lorenzo }\end{array}$ & $25(20)$ & $4(16)$ & $14(56)$ & $14(56)$ \\
\hline
\end{tabular}




\begin{tabular}{|c|c|c|c|c|}
\hline Regional Hospital of Coronel & $25(20)$ & $2(8)$ & $8(32)$ & $13(52)$ \\
\hline \multicolumn{5}{|l|}{ Oviedo } \\
\hline Regional Hospital of P.J. Caballero & $25(20)$ & $3(12)$ & $16(64)$ & $15(60)$ \\
\hline General Hospital of San Pedro & $25(20)$ & $0(0)$ & $8(32)$ & $8(32)$ \\
\hline IPS Hospital of Coronel Oviedo & $25(20)$ & $0(0)$ & $15(60)$ & $18(72)$ \\
\hline \multicolumn{5}{|l|}{ Work area } \\
\hline Consulting room & $49(39.2)$ & $4(8.1)$ & $26(53.1)$ & $27(55.1)$ \\
\hline Laboratory & $7(5.6)$ & $0(0)$ & $3(42.8)$ & $5(71.4)$ \\
\hline Respiratory ward & $10(8.0)$ & $2(20)$ & $5(50)$ & $5(50)$ \\
\hline ICU & $1(0.8)$ & $0(0)$ & $0(0)$ & $0(0)$ \\
\hline Emergency Department & $37(29.6)$ & $2(5.4)$ & $17(45.9)$ & $22(59.5)$ \\
\hline Surgery & $8(10.4)$ & $1(7.7)$ & $9(69.2)$ & $8(61.5)$ \\
\hline Other & $13(10.4)$ & $0(0)$ & $1(12.5)$ & $1(12.5)$ \\
\hline \multicolumn{5}{|l|}{ Resting place after work shifts } \\
\hline Temporary lodging & $6(4.8)$ & $1(16.7)$ & $4(66.7)$ & $4(66.7)$ \\
\hline Home & $119(95.2)$ & $8(6.7)$ & 57 (47.9) & $64(53.8)$ \\
\hline \multicolumn{5}{|l|}{ Availability of Personal Protective } \\
\hline \multicolumn{5}{|l|}{ Equipment } \\
\hline Never & $10(8.0)$ & $1(10)$ & $7(70)$ & $5(50)$ \\
\hline Rarely & $10(8.0)$ & $1(10)$ & $4(40)$ & $2(20)$ \\
\hline Sometimes & $13(10.4)$ & $1(7.7)$ & $8(61.5)$ & $7(53.8)$ \\
\hline Almost always & $47(37.6)$ & $3(6.4)$ & $18(38.3)$ & $29(61.7)$ \\
\hline Always & $45(36.0)$ & $3(6.7)$ & $24(53.3)$ & $25(55.6)$ \\
\hline
\end{tabular}

\#: PTSD: Post-Traumatic Stress Disorder. COVID-19: Coronavirus Disease in 2019. \#: PTSD-checklist. §: The Patient Health Questionnaire (PHQ-9). *: Generalized Anxiety Disorder scale (GAD-7)

\section{DISCUSSION}

The present cross-sectional pilot study included 125 participants and revealed a high prevalence of psychological symptoms among healthcare workers involved in the management of patients with COVID-19 in Paraguay. Approximately half of the subjects reported symptoms of anxiety and depression, while less than $10 \%$ presented symptoms of post-traumatic stress.

To the best of our knowledge, this is one the first studies in Latin America on the prevalence of symptoms of post-traumatic stress, depression and anxiety in healthcare workers occupationally exposed to SARS-CoV-2. A study involving 204 Latin American surgeons has shown that $22 \%(n=45)$ of them had a score over 10 in the PHQ-9); they were not assessed for anxious or post-traumatic stress symptoms (17).

The prevalence of $7.2 \%$ of PTSD symptoms is similar to previous studies conducted during the SARS pandemic, which was in the range between $5 \%$ and $10 \%$, and also similar to the prevalence of severe PTSD symptoms (6.2\% to $10.5 \%)$ found in recent studies in China $(4,7$, 18). In addition, frontline healthcare workers occupationally exposed to COVID-19 had a higher prevalence of post-traumatic stress symptoms, similar to a previous study conducted during the COVID-19 pandemic (7).

In our sample, a large proportion presented symptoms of anxiety and depression, $54.4 \%$ and $48.8 \%$, respectively. The prevalence rates of depressive and anxious symptoms are similar to those described in the studies conducted during the SARS epidemic and other reports published during the COVID-19 pandemic (5, 7): higher rates of anxiety and depression in frontline healthcare workers (especially in nurses) were found compared to healthcare workers not-occupationally exposed workers to SARS-CoV-2 (19-21). Limitations of this study include a small sample size and a disproportionately large representation of doctors (7, 20).

The higher prevalence of symptoms of depression and anxiety in females is in line with previous studies in healthcare workers and in the general population. This suggests a vulnerability of females to suffer from psychological distress during high stress situations such as epidemics or pandemics (22).

Regarding the limitations of the study, the crosssectional nature, the sample size and the nonprobabilistic sampling are worth noting. We hope that the full study with a larger sample size and detailed statistical analyses will shed light on the prevalence of psychological distress and post-traumatic stress in healthcare workers and its association or lack of association with occupational exposure to SARS-CoV-2.

This preliminary study was conducted among Paraguayan healthcare workers exposed or not exposed to COVID-19. Workers exposed to COVID-19 reported a high prevalence of symptoms of depression, anxiety. This suggests that prevention of mental health 
issues and psychological distress among healthcare workers is mandatory (23).

Our following research study will add more details and information regarding the unexplored psychological impact of COVID-19 among healthcare workers in Paraguay.

\section{REFERENCES}

1. Mohindra R, R Mahindra, Suri V, Bhalla A, Singh SM. Issues relevant to mental health promotion in frontline health care providers managing quarantined/isolated COVID19 patients. Asian J Psychiatr. 2020;51:102084. https://doi.org/10.1016/j.ajp.2020.102084

2. Brooks SK, Webster RK, Smith LE, Woodland L, Wessely S, Greenberg N, et al. The psychological impact of quarantine and how to reduce it: rapid review of the evidence. Lancet. 2020;395(10227):912-920. https://doi.org/10.1016/S01406736(20)30460-8

3. Chua SE, Cheung V, Cheung C, McAlonan GM, Wong JW, Cheung EP, et al. Psychological effects of the SARS outbreak in Hong Kong on high-risk health care workers. Can J Psychiatry. 2004;49(6):391-3. https://doi.org/10.1177/070674370404900609

4. Bai Y, Lin CC, Lin CY, Chen JY, Chue CM, Chou P. Survey of stress reactions among health care workers involved with the SARS outbreak. Psychiatr Serv. 2004;55(9):1055-7. https://doi.org/10.1176/appi.ps.55.9.1055

5. Lee AM, Wong JG, McAlonan GM, Cheung V, Cheung C, Sham PC, et al. Stress and psychological distress among SARS survivors 1 year after the outbreak. Can J Psychiatry. 2007;52(4):233-40.

https://doi.org/10.1177/070674370705200405

6. Wu P, Fang $Y$, Guan Z, Fan B, Kong J, Yao Z, et al. The psychological impact of the SARS epidemic on hospital employees in China: exposure, risk perception, and altruistic acceptance of risk. Can J Psychiatry. 2009;54(5):302-11.

https://doi.org/10.1177/070674370905400504

7. Lai J, Ma S, Wang Y, Cai Z, Hu J, Wei N, et al. Factors Associated With Mental Health Outcomes Among Health Care Workers Exposed to Coronavirus Disease 2019. JAMA Netw Open. 2020;3(3):e203976. https://doi.org/10.1001/jamanetworkopen.2020.3976

8. Lozano Díaz A, Fernández-Prados JS, Figueredo Canosa V, Martínez Martínez AM. Impactos del confinamiento por el COVID-19 entre universitarios: Satisfacción Vital, Resiliencia y Capital Social Online [Impacts of confinement due to COVID-19 among university students: Life Satisfaction, Resilience and Online Social Capital]. International Journal of Sociology of Education, Special Issue: COVID-19 Crisis and Socioeducative Inequalities and Strategies to Overcome them

2020:79-104.

https://doi.org/10.17583/rise.2020.592

9. Rios-González CM, Palacios JM. Symptoms of Anxiety and depression during the outbreak of COVID-19 in Paraguay. Version: 1. SciELO [Preprint]. [posted 2020 Apr 24; revised; cited 2020 Jun 15]: [10 p.]. Available from: https://preprints.scielo.org/index.php/scielo/preprint/vie w/152

10. Diez-Quevedo C, Rangil T, Sanchez-Planell L, Kroenke K, Spitzer RL. Validation and utility of the patient health questionnaire in diagnosing mental disorders in 1003 general hospital Spanish inpatients. Psychosom Med. 2001;63(4):679-86. https://doi.org/10.1097/00006842-
200107000-00021

11. Tomitaka S, Kawasaki $\mathrm{Y}$, Ide $\mathrm{K}$, Akutagawa $\mathrm{M}$, Yamada $\mathrm{H}$, Ono $Y$, Furukawa TA. Distributional patterns of item responses and total scores on the PHQ-9 in the general population: data from the National Health and Nutrition Examination Survey. BMC Psychiatry. 2018;18(1):108. https://doi.org/10.1186/s12888-018-1696-9

12. García-Campayo J, Zamorano E, Ruiz MA, Pardo A, PérezPáramo M, López-Gómez V, et al. Cultural adaptation into Spanish of the generalized anxiety disorder-7 (GAD-7) scale as a screening tool. Health Qual Life Outcomes. 2010;8:8. https://doi.org/10.1186/1477-7525-8-8

13. Vera-Villarroel P, Zych I, Celis-Atenas K, Córdova-Rubio N, Buela-Casal G. Chilean validation of the Posttraumatic Stress Disorder Checklist-Civilian version (PCL-C) after the earthquake on February 27, 2010. Psychol Rep. 2011;109(1):47-58. https://doi.org/10.2466/02.13.15.17.PRO.109.4.47-58

14. Spoont M, Arbisi P, Fu S, Greer N, Kehle-Forbes S, Meis L, et al. Screening for Post-Traumatic Stress Disorder (PTSD) in Primary Care: A Systematic Review [Internet]. Washington (DC): Department of Veterans Affairs (US); 2013.

15. Conybeare D, Behar E, Solomon A, Newman MG, Borkovec TD. The PTSD Checklist-Civilian Version: reliability, validity, and factor structure in a nonclinical sample. J Clin Psychol. 2012;68(6):699-713. https://doi.org/10.1002/jclp.21845

16. Weathers, F.W.; Litz, B.T.; Herman, D.S.; Huska, J.A.; Keane, T.M. The PTSD Checklist: Reliability, validity, and diagnostic utility. Int. Soc. Traum. Stress Stud. 1993; 2:9092.

17. Guiroy A, Gagliardi M, Coombes N, Landriel F, Zanardi C, Camino Willhuber G, et al. COVID-19 Impact Among Spine Surgeons in Latin America. Global Spine Journal. 2020. https://doi.org/10.1177/2192568220928032

18. Kang L, Ma S, Chen M, Yang J, Wang Y, Li R, et al. Impact on mental health and perceptions of psychological care among medical and nursing staff in Wuhan during the 2019 novel coronavirus disease outbreak: A cross-sectional study. Brain Behav Immun. 2020;87:11-17. https://doi.org/10.1016/j.bbi.2020.03.028

19. Qiu J, Shen B, Zhao M, Wang Z, Xie B, Xu Y. A nationwide survey of psychological distress among Chinese people in the COVID-19 epidemic: implications and policy recommendations. Gen Psychiatr. 2020;33(2):e100213. https://doi.org/10.1136/gpsych-2020-100213

20. Cai $Q$, Feng $H$, Huang J, Wang $M$, Wang $Q$, Lu X, et al. The mental health of frontline and non-frontline medical workers during the coronavirus disease 2019 (COVID-19) outbreak in China: A case-control study. J Affect Disord. 2020;275:210-215.

https://doi.org/10.1016/i.jad.2020.06.031

21. Lu W, Wang H, Lin Y, Li L. Psychological status of medical workforce during the COVID-19 pandemic: A crosssectional study. Psychiatry Res. 2020;288:112936. https://doi.org/10.1016/j.psychres.2020.112936

22. Que J, Shi L, Deng J, Liu J, Zhang L, Wu S, et al. Psychological impact of the COVID-19 pandemic on healthcare workers: a cross-sectional study in China. Gen Psychiatr. 2020;33(3):e100259. https://doi.org/10.1136/gpsych-2020-100259

23. Torales J, O'Higgins M, Castaldelli-Maia JM, Ventriglio A. The outbreak of COVID-19 coronavirus and its impact on global mental health. International Journal of Social Psychiatry 2020;66(4):317-320. https://doi.org/10.1177/0020764020915212 